\title{
A Review of Translocation $T(6 ; 11)$ Renal Cell Carcinoma Tumors in the Adult Patient
}

\author{
Paulette Cutruzzula ${ }^{\mathrm{a}} \quad$ David Cahn $^{\mathrm{b}} \quad$ Dana Kivlin $^{\mathrm{b}} \quad$ Carmen Tong $^{\mathrm{b}}$ \\ Daniel Edwards ${ }^{c} \quad$ Melanie Amster ${ }^{c}$ \\ aPhiladelphia College of Osteopathic Medicine; ${ }^{b}$ Department of Urology, Einstein Healthcare Network; 'Department of Urology, \\ Hahnemann University Hospital, Philadelphia, Pa. USA
}

\section{Key Words}

Translocation renal cell carcinoma $\bullet \mathrm{t}(6 ; 11) \mathrm{RCC}$.

MiT family translocation carcinomas •

Immunohistochemistry • Renal tumors

\begin{abstract}
Historically, $\mathrm{T}(6 ; 11)$ renal cell carcinoma (RCC) has been associated with the pediatric and adolescent populations and documentation of this tumor in adults has been rare. However, the frequency of translocation renal cell carcinoma (TRCC) may be widely underestimated in the adult population due to an inadequate immunohistochemical workup or misdiagnosis from similar gross and histological findings to other RCC. A subset of MiT family translocation carcinomas, $\mathrm{t}(6: 11)(\mathrm{p} 21 ; \mathrm{q} 12)$ translocation tumors cause an alpha-TFEB gene fusion. Morphologically, this neoplasm tends to mimic the various types of RCC's, including clear cell, papillary, and even epitheloid angiomyolipomas. Adult cases of TRCC have shown to behave more aggressively than their indolent pediatric counterpart, but due to the limited number of reported cases the true nature of these tumors has yet to be determined. The aim of this review is to bring an awareness of translocation RCC to better understand its diagnoses, treatment and prognosis, and, in turn, to allow for new cases to further highlight the behavior of this rare variant.
\end{abstract}

Copyright $\odot 2016$ S. Karger AG, Basel
() 2016 S. Karger AG, Basel

KARGER

Fax +4161306 1234

E-Mail karger@karger.com Accessible online at:

$\begin{array}{ll}\text { www.karger.com } & \text { www.karger.com/cur }\end{array}$

\section{Introduction}

$\mathrm{T}(6 ; 11)$ translocation renal cell carcinoma (TRCC) is an extremely rare variant and accounts for $0.02 \%$ of all renal carcinomas [1]. Approximately 50 cases have been documented in the literature, the majority of which occurring in children and adolescents, however, more recent literature has demonstrated that these neoplasms can present in adults as well [2]. The mean and median age of presentation is 31 years, with a wide reported range of 3-68 years [2]. The only identified risk factor has been previous treatment with cytotoxic chemotherapy [2].

First described in 2001 by Argani et al, TRCC was not recognized as a new clinical entity by the International Society of Urological Pathology until 2012, where it was determined to be a subtype of the MiT family translocation carcinomas, which includes the more common Xp11 TRCC $[3,4]$.

Genetically, the $\mathrm{t}(6 ; 11)$ translocation is a fusion of the 5 ' portion of the Alpha gene, an un-translated gene of unknown function, mapped at 11q12 with the transcription factor EB (TFEB) gene located at 6p21 [4]. This fusion results in the overexpression of native TFEB proteins that can be specifically identified on immunohistochemistry [5]. Although the mechanisms though which these fusions contribute to oncogenesis remains unclear, several studies suggest that the translocation facor E3 fusion 
proteins seen in other MiT family RCC are transcription activators [6]. Similarly to Xp11.2 TRCC, the origin of $\mathrm{t}(6 ; 11) \mathrm{RCC}$ is suggested to be from the proximal tubules of the nephron based on the ultrastructural identification of the rudimentary microvilli $[7,8]$.

\section{Pathologic Evaluation}

Since MiT RCCs appear grossly similar to clear cell RCC and immunohistochemistry is not routinely performed as standard pathologic practice for adult renal tumors, adult MiT family translocation carcinomas are often misclassified as clear cell RCC in daily practice [2]. This specific subtype is not identifiable on pre-operative imaging, and reports demonstrate that these neoplasms are distinctive only at the morphological, immunohistochemical, and cytogenic levels [9]. T(6;11) TRCC harbors a specific alpha-TFEB gene fusion which can be detected by reverse transcriptase polymerase chain reaction or by fluorescence in situ hybridization [2, 10]. While TRCCs do not have a distinctive gross appearance, reports indicate that these tumors have generally been un -encapsulated and exhibited a mahogany color and soft texture [2]. Histologically, these tumors are biphasic consisting of large and small epithelioid cells, which often form nests of rosettes clustered around the basement membrane [4].

The immunohistologic features are most distinctive and helpful in enabling an accurate diagnosis. Previous literature reports that most $\mathrm{t}(6 ; 11) \mathrm{RCCs}$ melanocytic markers are homatropine methylbromide 45 (HMB45) and Melan-A are positive and traditionally TRCC immunostains negative for translocation facor E3 as well as cytokeratins and epithelial memberane antigen $[9,11$, 12]. Smith et al demonstrated $\mathrm{t}(6 ; 11) \mathrm{RCC}$ labeled diffusely for cathpesin K (83\% mean labeling) and Melan A (92\% mean labeling), and less extensively for HMB45 [3]. A report from John Hopkins demonstrated immunohistochemical labeling for paired box 8, cathepsin $\mathrm{K}$, and Melan A in absence of cytokeratine AE1/3 is suggestive of $t(6 ; 11)$ RCC [3]. While these characteristics aid in accurate diagnosis, it is noteworthy that immunoreactivity for melanocytic markers HMB45 and Melan A and immune negativity for epithelial markers pan cytokeratin and epithelial memberane antigenmay lead to another misdiagnosis of angiomyolipoma [12]. Ultimately, the identification of these neoplasms as TRCC should be confirmed definitively by TFEB fluorescence in situ hybridization (FISH) studies [3, 12].

\section{Outcomes}

$\mathrm{T}(6 ; 11)$ RCC is recognized mostly as low-grade non-aggressive tumor. There are no well-established prognostic markers or protocols predicting biological behavior that are applicable for $\mathrm{t}(6 ; 11)$ RCC. Recommendations from the International Society of Urological Pathology Consensus Conference, state that behavior of these tumors is yet to be fully characterized, although $10 \%$ of the 30 reported cases have developed fatal metastatic disease [13]. Some adult cases have presented with metastasis or pursued an aggressive clinical course causing death $[6,7,14]$. While most cases affecting children and young adults seem to be rather indolent, recurrence occurs in $17 \%$ of these patients [6]. In a comparative study of 6 cases of $t(6 ; 11)$ RCC, Peckova et al. [5] found that age and necrosis could potentially be taken as independent adverse prognostic factors. On multivariate analysis, demonstrated that more aggressive $\mathrm{t}(6 ; 11) \mathrm{RCC}$ appeared to affect the older (mean 45.2 years) rather than younger patients (mean 31.5 years) [5]. Additionally, grossly visible necrosis was present in aggressive $t(6 ; 11)$ RCC only [5]. There are currently no well-established prognostic models predicting biological behavior that are applicable for $\mathrm{t}(6 ; 11)$ TRCC [5].

\section{Postoperative Surveillance}

The behavior of $\mathrm{t}(6 ; 11) \mathrm{RCC}$ remains unestablished due to the limited number cases in the literature. Extirpative surgery remains the lone therapeutic strategy as no proven neoadjuvant or adjuvant therapies exist. The recommendation for follow-up in adult patients is undetermined at this time. However, given the more aggressive behavior in adult populations as well as the potential for recurrence and metastasis, a more aggressive post-operative follow-up may be warranted $[5,10,15]$.

\section{Future Research}

Future cases of $\mathrm{t}(6 ; 11) \mathrm{RCC}$ will further delineate the incidence, epidemiology, and nature of this tumor. Studies utilizing emerging genomic technologies will help identify prognostic factors and therapeutic targets in these neoplasms [2]. Some case reports on the MiT translocation family have shown varied responses to mammalian target of rapamycin (mTOR) inhibitors [16]. Lastly whole genome DNA and RNA sequencing studies 
have recently been performed on a small number of cases of the MIT family translocation RCCs and hoped that these studies will identify therapeutic targets [17].

Currently there are a few clinical trials evaluating response and survival rates of different therapeutic agents. Underway, is a phase 2 trial evaluating MiT family cancers overall response to treatment with ARQ 197, a drug directed at blocking the c-Met pathway [18]. Another study at MD Anderson Cancer Center is assessing the progression free survival time of all non-clear cell renal cancers, including TRCC, in patients treated with Everolimus as compared to Sunitinib [19]. The results of these clinical trials will help direct the care of patients with these atypical tumors.

\section{Conclusion}

$\mathrm{T}(6 ; 11) \mathrm{RCC}$ is an uncommon tumor, found predominantly in children and adolescents. It is now clear that this tumor presents in adults as well, often with a worse prognosis [15]. Awareness and knowledge of this rare tumor and its unique immunohistological and morphological features will help to establish an accurate diagnosis to help delineate aggressive follow up. Future studies are needed to better understand tumor biology to create multispecialty guidelines to optimize patient care.

\section{References}

1 Geller JI, Argani P, Adeniran A, Hampton E, De Marzo A, Hicks J, Collins MH: Translocation renal cell carcinoma: lack of negative impact due to lymph node spread. Cancer 2008;112:1607-1616.

2 Argani P: MiT family translocation renal cell carcinoma. Semin Diagn Pathol 2015;32: 103-113.

3 Smith NE, Illei PB, Allaf M, Gonzalez N, Morris K, Hicks J, Demarzo A, Reuter VE, Amin MB, Epstein JI, Netto GJ, Argani P: $\mathrm{t}(6 ; 11)$ renal cell carcinoma $(\mathrm{RCC})$ : expanded immunohistochemical profile emphasizing novel RCC markers and report of ten new genetically-confirmed cases. Am J Surg Pathol 2014;38:604-614.

4 Srigley JR, Delahunt B, Eble JN, Egevad L, Epstein JI, Grignon D, Hes O, Moch H, Montironi R, Tickoo SK, Zhou M, Argani P: The International Society of Urological Pathology (ISUP) Vancouver classification of renal neoplasia. Am J Surg Pathol 2013;37:1469_ 1489.

5 Peckova K, Vanecek T, Martinek P, Spagnolo D, Kuroda N, Brunelli M, Vranic S, Djuricic S, Rotterova P, Daum O, Kokoskova B, Vesela P, Pivovarcikova K, Bauleth K, Dubova M, Kalusova K, Hora M, Michal M, Hes O: Aggressive and nonaggressive translocation $\mathrm{t}(6 ; 11)$ renal cell carcinoma: comparative study of 6 cases and review of the literature. Ann Diagn Pathol 2014;18:351-357.

6 Pecciarini L, Cangi MG, Lo Cunsolo CL, Macri'E, Dal Cin E, Martignoni G, Doglioni C: Characterization of $\mathrm{t}(6 ; 11)(\mathrm{p} 21 ; \mathrm{q} 12)$ in a renal-cell carcinoma of an adult patient. Genes Chromosomes Cancer 2007;46:419426.

7 Argani P, Ladanyi M: Translocation carcinomas of the kidney. Clin Lab Med 2005;25: 363-378.

$\mathrm{T}(6: 11)$ Renal Cell Carcinoma Tumors in the Adult Patient
8 Medendorp K, van Groiningen JJ, Schepens M, Vreede L, Thijssen J, Schoenmakers EF, van den Hurk WH, Geurts van Kessel A, Kuiper RP: Molecular mechanisms underlying the MiT translocation subgroup of renal cell carcinomas. Cytogenet Genome Res 2007; 118:157-165.

9 Argani P, Hawkins A, Griffin CA, Goldstein JD, Haas M, Beckwith JB, Mankinen CB, Perlman EJ: A distinctive pediatric renal neoplasm characterized by epithelioid morphology, basement membrane production, focal HMB45 immunoreactivity, and $t(6 ; 11)$ (p21.1;q12) chromosomal translocation. Am J Pathol 2001;158:2089-2096.

10 Kuroda N, Tanaka A, Sasaki N, Ishihara A, Matsuura K, Moriyama M, Nagashima Y, Inoue $\mathrm{K}$, Petersson F, Martignoni G, Michal $\mathrm{M}$, Hes $\mathrm{O}$ : Review of renal carcinoma with $\mathrm{t}(6 ; 11)(\mathrm{p} 21 ; \mathrm{q} 12)$ with focus on clinical and pathobiological aspects. Histol Histopathol 2013;28:1026-1032.

11 Camparo P, Vasiliu V, Molinie V, Couturier J, Dykema KJ, Petillo D, Furge KA, Comperat EM, Lae M, Bouvier R, Boccon-Gibod L, Denoux Y, Ferlicot S, Forest E, Fromont G, Hintzy MC, Laghouati M, Sibony M, Tucker ML, Weber N, Teh BT, Vieillefond A: Renal translocation carcinomas: clinicopathologic, immunohistochemical, and gene expression profiling analysis of 31 cases with a review of the literature. Am J Surg Pathol 2008;35: 656-670.

12 Arneja SK, Gujar N: Renal cell carcinoma with $t(6 ; 11)(\mathrm{p} 21 ; \mathrm{q} 12)$. A case report highlighting distinctive immunohistologic features of this rare tumor. Int J Surg Case Rep 2015;7C:16-19.
13 Ross H, Argani P: Xp11 translocation renal cell carcinoma. Pathology 2010;42:369-373.

14 Inamura K, Fujiwara M, Togashi Y, Nomura K, Mukai H, Fujii Y, Yamamoto S, Yonese J, Fukui I, Ishikawa Y: Diverse fusion patterns and heterogeneous clinicopathologic features of renal cell carcinoma with $\mathrm{t}(6 ; 11)$ translocation. Am J Surg Pathol 2012;36:35-42.

15 Rao Q, Xia QY, Cheng L, Zhou XJ: Molecular genetics and immunohistochemistry characterization of uncommon and recently described renal cell carcinomas. Chin J Cancer Res 2016;28:29-49.

16 Pfluger D, Sboner A, Storz M, Roth J, Compérat E, Bruder E, Rubin MA, Schraml $\mathrm{P}$, Moch H: Identification of molecular tumor markers in renal cell carcinomas with TFE3 protein expression by RNA sequencing. Neoplasia 2013;15:1231-1240.

17 Malouf GG, Camparo P, Oudard S, Schleiermacher G, Theodore C, Rustine A, Dutcher J, Billemont B, Rixe O, Bompas E, Guillot A, Boccon-Gibod L, Couturier J, Molinié V, Escudier B: Targeted agents in metastatic Xp11 translocation/TFE3 gene fusion renal cell carcinoma (RCC): a report from the Juvenile RCC Network. Ann Oncol 2010;21:1834 1838 .

18 ArQule: Phase 2 study of ARQ 197 in patients with micropthalmia transcription factor associated tumors; in: ClinicalTrials.gov. NCT00557609, 2016.

19 MD Anderson Cancer Center: Everolimus versus Sunitinib therapy in patients with nonclear cell renal cell carcinoma; in: ClinicalTrials.gov. NCT01185366, 2016. 